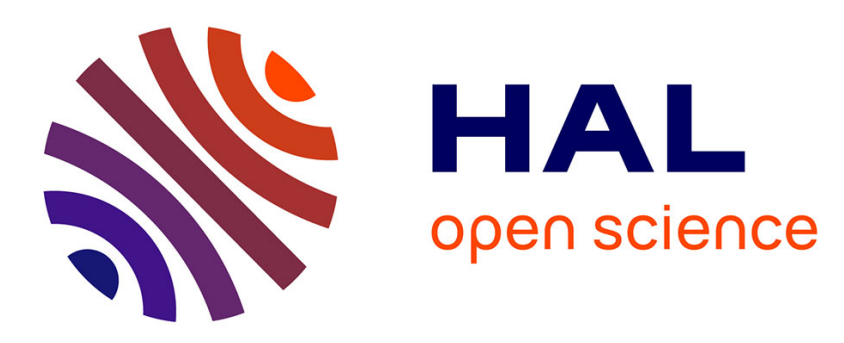

\title{
Outstanding room-temperature capacitance of biomass-derived microporous carbons in ionic liquid electrolyte
}

Edurne Redondo, Wan-Yu Tsai, Barbara Daffos, Pierre-Louis Taberna, Patrice Simon, Eider Goikolea, Roman Mysyk

\section{To cite this version:}

Edurne Redondo, Wan-Yu Tsai, Barbara Daffos, Pierre-Louis Taberna, Patrice Simon, et al.. Outstanding room-temperature capacitance of biomass-derived microporous carbons in ionic liquid electrolyte. Electrochemistry Communications, 2017, 79, pp.5-8. 10.1016/j.elecom.2017.04.004 . hal01556598

\section{HAL Id: hal-01556598 \\ https://hal.science/hal-01556598}

Submitted on 5 Jul 2017

HAL is a multi-disciplinary open access archive for the deposit and dissemination of scientific research documents, whether they are published or not. The documents may come from teaching and research institutions in France or abroad, or from public or private research centers.
L'archive ouverte pluridisciplinaire HAL, est destinée au dépôt et à la diffusion de documents scientifiques de niveau recherche, publiés ou non, émanant des établissements d'enseignement et de recherche français ou étrangers, des laboratoires publics ou privés. 


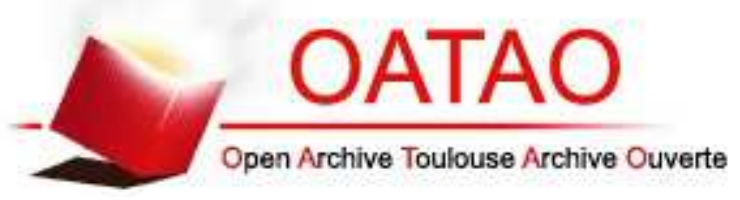

\section{Open Archive TOULOUSE Archive Ouverte (OATAO)}

OATAO is an open access repository that collects the work of Toulouse researchers and makes it freely available over the web where possible.

This is an author-deposited version published in : http://oatao.univ-toulouse.fr/ Eprints ID : 18013

To link to this article : DOI: $10.1016 / j . e l e c o m .2017 .04 .004$

URL : http://dx.doi.org/10.1016/j.elecom.2017.04.004

To cite this version : Redondo, Edurne and Tsai, Wan-Yu and

Daffos, Barbara and Taberna, Pierre-Louis and Simon, Patrice and

Goikolea, Eider and Mysyk, Roman Outstanding room-temperature capacitance of biomass-derived microporous carbons in ionic liquid electrolyte. (2017) Electrochemistry Communications, vol. 79. pp.

5-8. ISSN 1388-2481

Any correspondence concerning this service should be sent to the repository administrator: staff-oatao@ listes-diff.inp-toulouse.fr 


\title{
Outstanding room-temperature capacitance of biomass-derived microporous carbons in ionic liquid electrolyte
}

\author{
Edurne Redondo ${ }^{\mathrm{a}}$, Wan-Yu Tsai ${ }^{\mathrm{b}, \mathrm{c}}$, Barbara Daffos ${ }^{\mathrm{b}, \mathrm{c}}$, Pierre-Louis Taberna ${ }^{\mathrm{b}, \mathrm{c}}$, Patrice Simon ${ }^{\mathrm{b}, \mathrm{c}, *}$, \\ Eider Goikolea $^{\mathrm{a}}$, Roman Mysyk ${ }^{\mathrm{a}, * *}$ \\ ${ }^{a}$ CIC Energigune, Arabako Teknologi Parkea, Albert Einstein 48, 01510 Miñano, Spain \\ ${ }^{\mathrm{b}}$ Université Paul Sabatier Toulouse III, Institut Carnot CIRIMAT, UMR CNRS 5085, 118 route de Narbonne, 31062 Toulouse, France \\ ${ }^{\mathrm{c}}$ Réseau sur le Stockage Electrochimique de l'Energie (RS2E), FR CNRS 3459, France
}

\begin{abstract}
A B S T R A C T
A remarkable capacitance of $180 \mathrm{~F} \cdot \mathrm{g}^{-1}$ (at $5 \mathrm{mV} \cdot \mathrm{s}^{-1}$ ) in solvent-free room-temperature ionic liquid electrolyte, 1-ethyl-3-methylimidazolium bis(trifluoromethylsulfonyl)imide, was achieved in symmetric supercapacitors using microporous carbons with a specific surface area of ca. $2000 \mathrm{~m}^{2} \cdot \mathrm{g}^{-1}$ calculated from gas sorption by the 2D-NLDFT method. The efficient capacitive charge storage was ascribed to textural properties: unlike most activated carbons, high specific surface area was made accessible to the bulky ions of the ionic liquid electrolyte thanks to micropores (1-2 nm) enabled by fine-tuning chemical activation. From the industrial perspective, a high volumetric capacitance of ca. $80 \mathrm{~F} \cdot \mathrm{cm}^{-3}$ was reached in neat ionic liquid due to the absence of mesopores. The use of microporous carbons from biomass waste represents an important advantage for large-scale production of high energy density supercapacitors.
\end{abstract}

\section{Introduction}

Electrical double layer capacitors (EDLCs) store charge by electrostatic interaction between electrolyte ions and electrode surface charges [1]. Room temperature ionic liquids (RTILs) [2] have been proposed as electrolytes for advanced and safe EDLCs for their wide stable electrochemical window, wide operational temperature range and non-volatility. However, RTILs exhibit high viscosity and low ionic conductivity at room temperature; hence, electrolyte ions have hindered access into the narrow micropores of commercial activated carbons (ACs). Thus, RTIL-based supercapacitors often show low capacitance and high resistance compared to those using conventional electrolytes, based on organic solvents (acetonitrile or propylene carbonate) $[3,4,5,6]$. In this regard, two different approaches have been pursued to circumvent the drawbacks of RTILs and make them efficient in supercapacitors: i) dissolving RTILs in small amounts of organic solvents to increase ionic conductivity [7], and ii) employing electrode materials with fully electrolyte-accessible (open) surface, such as exohedral carbons [8] or mesoporous carbons [9]. The first approach is achieved detrimentally to the maximum cell voltage. The second cannot provide high capacitance (due to the low specific surface area (SSA) of such materials), and also requires complex synthetic procedures and/or expensive synthetic precursors. Recent investigations demonstrated improvements in gravimetric capacitance by combining RTILs containing 1-ethyl-3-methylimidazolium $\left(\mathrm{EMI}^{+}\right)$ion and micro/mesoporous carbons with high pore volume $\left(\sim 2 \mathrm{~cm}^{3} \cdot \mathrm{g}^{-1}\right)[10,11]$. However, high mesopore volume is detrimental to the density of materials. Thus, volumetric capacitance, the most industry-demanded metric, can be adversely affected with such carbons.

In this work, a series of ACs derived from low-cost green precursors (olive pits) was synthesized [12] and tested as electrode materials in neat 1-ethyl-3-methylimidazolium bis(trifluoromethanesulfonyl)imide (EMI-TFSI) at room temperature. These carbons contain only micropores that can be easily fine-tuned through synthesis parameters. The results showed high gravimetric and volumetric capacitance using such mesopore-free materials and EMI-TFSI within $3 \mathrm{~V}$, thus offering interesting opportunities for industrial development since ACs come from cheap and abundant natural precursors.

\section{Experimental}

ACs were prepared by chemical $\mathrm{KOH}$ activation of olive pits, as reported elsewhere $[12,13]$. Briefly, the precursor was carbonized in a tubular furnace under an Ar flow of $100 \mathrm{~mL} \cdot \mathrm{min}^{-1}$ by heating at

\footnotetext{
* Correspondence to: P. Simon, Université Paul Sabatier Toulouse III, Institut Carnot CIRIMAT, UMR CNRS 5085, 118 route de Narbonne, 31062 Toulouse, France.

** Corresponding to: R. Mysyk, CIC Energigune, Arabako Teknologi Parkea, Albert Einstein 48, 01510 Miñano, Spain

E-mail addresses: simon@chimie.ups-tlse.fr (P. Simon), rmysyk@cicenergigune.com (R. Mysyk).
} 
$5{ }^{\circ} \mathrm{C} \cdot \mathrm{min}^{-1}$ and dwelling for $2 \mathrm{~h}$ at $700{ }^{\circ} \mathrm{C}$. The samples of carbon char were mixed with different amounts of $\mathrm{KOH}$ and heated up under the same conditions described in the first step. Last, the ACs were washed off with diluted $\mathrm{HCl}$ and water until neutral $\mathrm{pH}$, and dried at $120^{\circ} \mathrm{C}$ under vacuum overnight.

$\mathrm{N}_{2}$ adsorption was conducted using an ASAP2460 instrument (Micromeritics). The samples were outgassed under vacuum at $250{ }^{\circ} \mathrm{C}$ for $24 \mathrm{~h}$ before analysis. $\mathrm{N}_{2}$ isotherms were measured at $77 \mathrm{~K}$ for relative pressures $\left(\mathrm{P} / \mathrm{P}_{0}\right)$ between $10^{-7}$ and 0.995 . The SSA and pore size distribution (PSD) were calculated using the SAIEUS software with 2D-NLDFT [14]. The differential pore volume (dV/dlgL) was calculated as:

$\mathrm{dV} / \mathrm{d} \lg \mathrm{L}=\mathrm{dV} / \mathrm{dL} \operatorname{Ln} 10$

Average pore size was calculated as the weighted average from PSD, according to Eqs. (2) or (3):

$\mathrm{L}_{0}=\int_{\mathrm{V}_{\text {min }}}^{\mathrm{V}_{\text {tot }}} \mathrm{LdV} /\left(\mathrm{V}_{\mathrm{tot}}-\mathrm{V}_{\text {min }}\right)$

$\mathrm{L}_{\mathrm{i}}=\int_{\mathrm{V}_{\mathrm{is}}}^{\mathrm{V}_{\text {tot }}} \mathrm{LdV} /\left(\mathrm{V}_{\mathrm{tot}}-\mathrm{V}_{\mathrm{is}}\right)$

where $\mathrm{L}_{0}$ and $\mathrm{L}_{\mathrm{i}}$ correspond to the average pore size and the average ion-inaccessible pore size, $\mathrm{L}$ the pore size, $\mathrm{V}_{\text {is }}$ the ion-inaccessible pore volume, and $\mathrm{V}_{\text {tot }}$ the total pore volume from the cumulative DFT distribution [12].

The electrodes were made by mixing $95 \mathrm{wt} \%$ of ACs with $5 \mathrm{wt} \%$ of polytetrafluoroethylene (PTFE) binder from a $60 \mathrm{wt} \%$ aqueous dispersion. The mixture was stirred in ethanol to form a dough further rolled to a thickness of $\sim 170 \mu \mathrm{m}$ and dried under vacuum at $120^{\circ} \mathrm{C}$ overnight. Disk electrodes of $11 \mathrm{~mm}$ diameter were cut out with the electrode mass between 7 and $8 \mathrm{mg} \cdot \mathrm{cm}^{-2}$. Two-electrode symmetric supercapacitors were assembled in Swagelok ${ }^{\circledast}$ cells using two identical activated carbon electrodes, a borosilicate glass fiber separator (Whatman GF/B) and EMI-TFSI, 99.9\% (Solvionic) as electrolyte. Cell assembly was conducted in a glove box under Ar atmosphere with $<1 \mathrm{ppm}$ of water and oxygen.

Electrochemical measurements were done at room temperature, $20{ }^{\circ} \mathrm{C}$, using a multichannel potentiostat/galvanostat VMP3 (Biologic): cyclic voltammetry (CV) at a scan rate of $5 \mathrm{mV} \cdot \mathrm{s}^{-1}$, galvanostatic cycling (GC) at $0.1-30 \mathrm{~A} \cdot \mathrm{g}^{-1}$ of active material per electrode and electrochemical impedance spectroscopy (EIS) from $1 \mathrm{MHz}$ to $10 \mathrm{mHz}$.

Gravimetric and volumetric electrode capacitance (C) was calculated using Eqs. (4) and (5), respectively:

$\mathrm{C}=2 \cdot \int \mathrm{Idt} /(\mathrm{U} \cdot \mathrm{m})$

$\mathrm{C}=2 \cdot \int \mathrm{Idt} /\left(\mathrm{U} \cdot \pi \cdot \mathrm{r}^{2} \cdot \mathrm{h}\right)$

where $\mathrm{I}$ is the current, $\mathrm{t}$ the discharge time, $\mathrm{U}$ the voltage, $\mathrm{m}$ the active material mass per electrode, $r$ the radius and $h$ the electrode thickness.

Series resistance was evaluated from the intercept of the real axis at high frequency of the Nyquist plot, and in-pore ionic resistance from the intercept of quasi-vertical line at low frequency with the real axis after excluding the series resistance [15].

\section{Results and discussion}

Textural properties are shown in Fig. 1 and Table 1. Since the maximum capacitance of carbide-derived porous carbons was found at pore size of $\sim 0.72 \mathrm{~nm}$ using neat EMI-TFSI [16], pores narrower than $0.70 \mathrm{~nm}$ are considered poorly accessible to electrolyte ions due to the ion-sieving effect. Ion-accessible pore volume and surface area calculated using this cut-off ( $>0.70 \mathrm{~nm}$ ), $\mathrm{d}_{50}$ and $\mathrm{d}_{90}$ are listed in Table 1. $d_{50}$ and $d_{90}$ are the pore widths corresponding to 50 and $90 \%$ of the
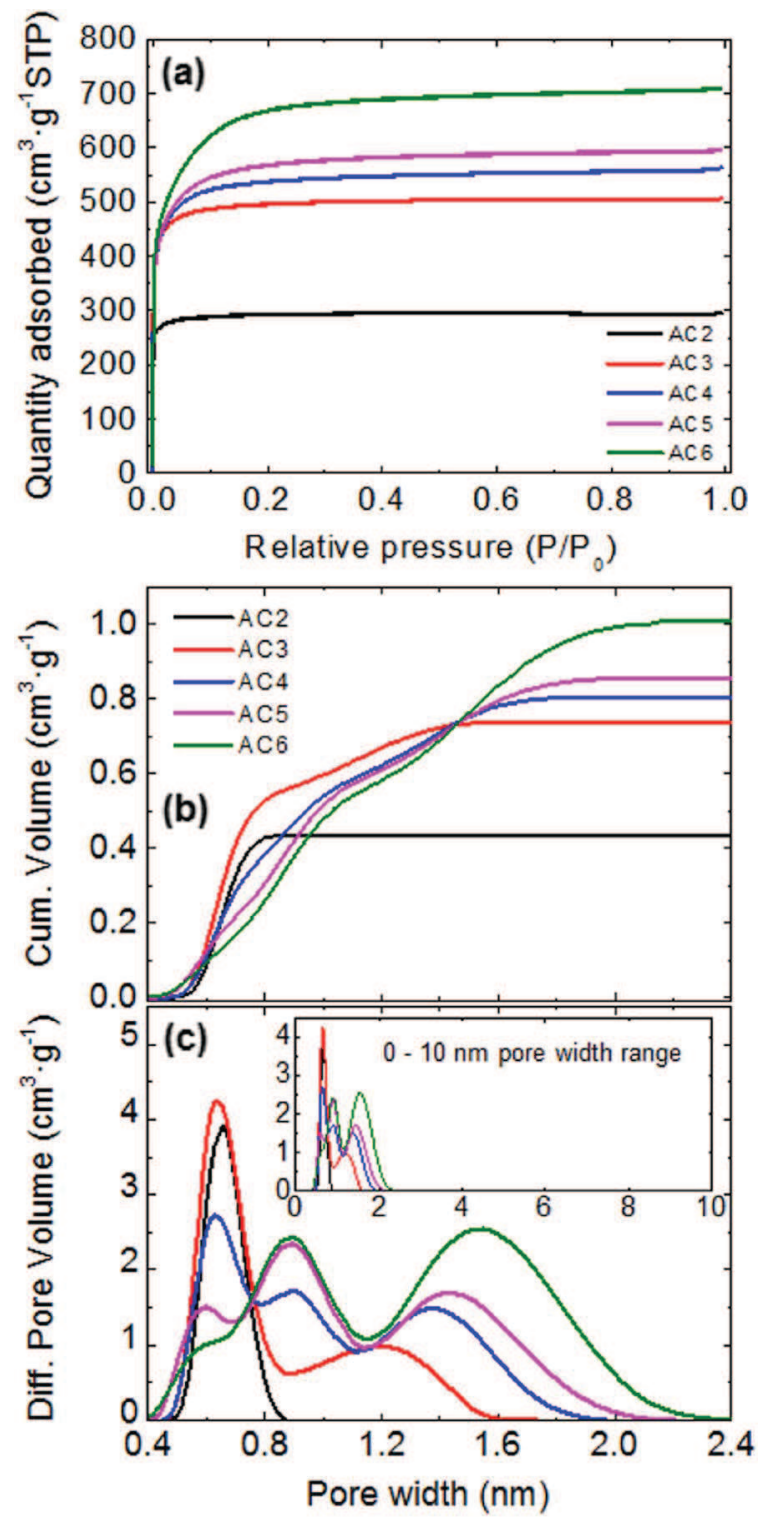

Fig. 1. (a) $\mathrm{N}_{2}$ adsorption/desorption isotherms (b) cumulative (c) differential pore volume $(\mathrm{dV} / \mathrm{dlgL})$ vs pore size calculated by the $2 \mathrm{D}$-NLDFT model.

total pore volume and their use was recently suggested for assessing PSD [17]. All the ACs have pores in the micropore range $(<2 \mathrm{~nm})$ and, as reported elsewhere [18], PSD is widened with the higher $\mathrm{KOH} /$ carbon ratio. Thus, AC2 exhibits the smallest $L_{0}$ and $d_{50}$ among the studied ACs. Although AC3-AC6 have similar SSA, an increasing $\mathrm{L}_{0}$ is observed from AC3 to AC6. Moreover, the difference between $d_{90}$ and $\mathrm{d}_{50}$ increases correspondingly, meaning higher pore size dispersity with more $\mathrm{KOH}$.

Fig. 2a and b show the CVs of symmetric cells for AC2-AC6 at $5 \mathrm{mV} \cdot \mathrm{s}^{-1}$ in EMI-TFSI. Most of the samples exhibit rectangular CVs typical of supercapacitors. Most importantly, high specific capacitance of $179 \mathrm{~F} \cdot \mathrm{g}^{-1}, 163 \mathrm{~F} \cdot \mathrm{g}^{-1}$ and $171 \mathrm{~F} \cdot \mathrm{g}^{-1}$ was measured for AC4, AC5 and AC6, respectively. To our knowledge, such high capacitance values have never been reported for purely microporous carbons in neat RTILs. By contrast, AC2 shows very low gravimetric capacitance since $d_{90}$ is below $0.75 \mathrm{~nm}$, thus poorly accessible to cations and anions, in agreement with the accessible SSA of only $292 \mathrm{~m}^{2} \mathrm{~g}^{-1}$ (Table 1). Compared with AC2, AC3 shows decent gravimetric capacitance with huge distortion at high polarisation, meaning that, even with higher SSA, not all the pores are easily accessible to the electrolyte. The increase in $d_{50}$ beyond $0.70 \mathrm{~nm}$ and the associated $L_{\mathrm{i}}$, such as that 
Table 1

Textural properties of the ACs.

\begin{tabular}{|c|c|c|c|c|c|c|c|c|c|}
\hline $\begin{array}{l}\text { Sample } \\
\text { Name }\end{array}$ & $\begin{array}{l}\text { KOH-carbon } \\
\text { Ratio }\end{array}$ & $\begin{array}{l}\text { DFT-SSA } \\
\left(\mathrm{m}^{2} \cdot \mathrm{g}^{-1}\right)\end{array}$ & $\begin{array}{l}\text { Volume } \\
\left(\mathrm{cm}^{3} \cdot \mathrm{g}^{-1}\right)\end{array}$ & $\mathrm{L}_{0}(\mathrm{~nm})$ & $\mathrm{d}_{50}(\mathrm{~nm})$ & $\mathrm{d}_{90}(\mathrm{~nm})$ & $\begin{array}{l}\text { DFT-SSA }(>0.70 \mathrm{~nm}) \\
\left(\mathrm{m}^{2} \cdot \mathrm{g}^{-1}\right)\end{array}$ & $\begin{array}{l}\text { Volume }(>0.70 \mathrm{~nm}) \\
\left(\mathrm{cm}^{3} \cdot \mathrm{g}^{-1}\right)\end{array}$ & $\mathrm{L}_{\mathrm{i}}(>0.70 \mathrm{~nm})(\mathrm{nm})$ \\
\hline AC2 & 2 & 1362 & 0.439 & 0.66 & 0.65 & 0.75 & 292 & 0.107 & 0.74 \\
\hline AC3 & 3 & 2048 & 0.738 & 0.78 & 0.68 & 1.19 & 713 & 0.328 & 0.97 \\
\hline AC4 & 4 & 1965 & 0.807 & 0.98 & 0.83 & 1.45 & 1031 & 0.523 & 1.14 \\
\hline AC5 & 5 & 1986 & 0.858 & 1.01 & 0.91 & 1.55 & 1223 & 0.642 & 1.15 \\
\hline AC6 & 6 & 2084 & 1.010 & 1.18 & 1.04 & 1.73 & 1486 & 0.844 & 1.30 \\
\hline
\end{tabular}

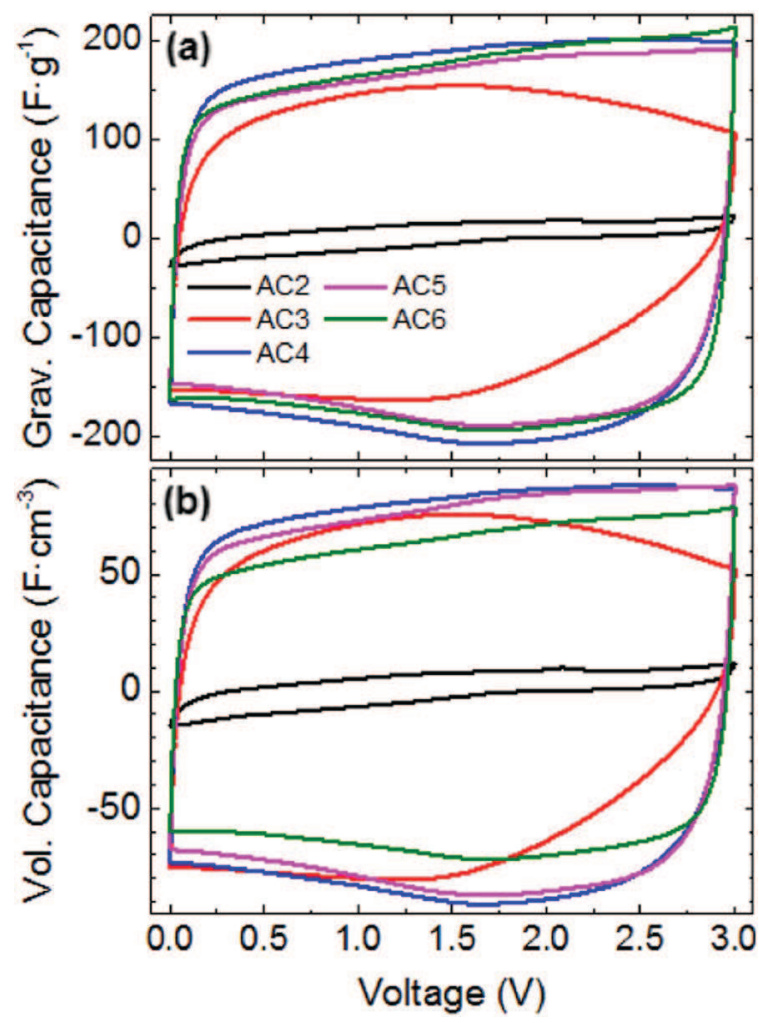

Fig. 2. Cyclic voltammograms of ACs from olive pits at a scan rate of $5 \mathrm{mV} \cdot \mathrm{s}^{-1}$ in neat EMI-TFSI at room temperature $\left[20^{\circ} \mathrm{C}\right]$ (a) gravimetric and (b) volumetric capacitance.

achieved for AC4, enable a nice typical capacitive signature within $3 \mathrm{~V}$. Thus, AC4 has a PSD wide enough to provide good access for $\mathrm{EMI}^{+}$and TFSI $^{-}$ions to a large part of microporous surface, also achieving high gravimetric capacitance. Further increasing $\mathrm{L}_{\mathrm{i}}$ shows no improvement in capacitance (from AC4 to AC6). The higher capacitance of AC4 vs AC5 can arise due to stronger ion confinement due to narrower PSD as suggested theoretically [19] and experimentally measured [16,17,22].

More interestingly, Fig. $2 \mathrm{~b}$ shows that a high volumetric capacitance of 80,75 and $63 \mathrm{~F} \cdot \mathrm{cm}^{-3}$ was achieved for AC4, AC5 and AC6, respectively. Such high values in RTILs are unusual for biomass-derived microporous carbons with irregular porosity and are comparable or even higher than in solvent-based electrolytes [20]. Since the volumetric capacitance is a key parameter from industrial prospective regarding device miniaturization, these results are highly promising for the energy density of devices. Obviously, high volumetric capacitance was achieved thanks to the moderate pore volume in strictly microporous carbons, which distinguishes them from carbons with ultrahigh-pore volume $\left(\sim 2 \mathrm{~cm}^{3} \cdot \mathrm{g}^{-1}\right)$ that also provide high gravimetric capacitance, but have significant mesoporosity, which is detrimental to volumetric performance [9]. A recent study [21] also reports high gravimetric capacitance in neat IL electrolyte for a carbon with $\sim 20 \%$ higher pore volume than that of AC4, detrimentally to the volumetric capacitance (not calculated).

Rate capability is an important metric in supercapacitor perfor-
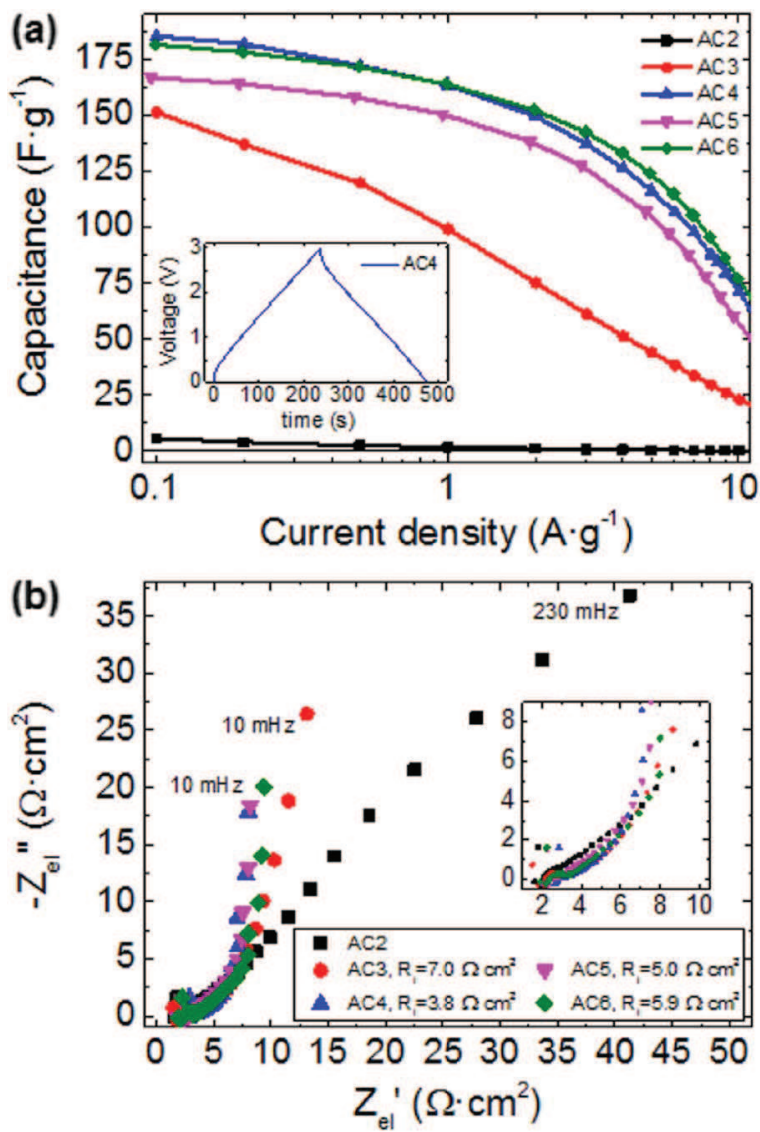

Fig. 3. (a) Capacitance of ACs in neat EMI-TFSI as a function of current density (inset galvanostatic charge-discharge profile at $1 \mathrm{~A} \cdot \mathrm{g}^{-1}$ ); (b) Nyquist plot $\mathrm{Ohm} \cdot \mathrm{cm}^{2}$ per electrode (inset - high frequency range).

mance, which depends on the complex interplay between textural and electrical properties of porous carbons and in-pore ion transport $[22,23]$. Fig. 3 shows that capacitance retention is poor for AC2 and AC3, due to the poorly accessible porous structure. It increases for AC4-AC6 showing similar capacitance retention of $\sim 65 \%$ at $5 \mathrm{~A} \cdot \mathrm{g}^{-1}$ and $\sim 40 \%$ at $10 \mathrm{~A} \cdot \mathrm{g}^{-1}$. The similar capacitance retention for AC4 to AC6 evidences that AC4 provides a well-suited PSD to ensure not only high capacitance, but also sufficiently fast ion transport in micropores. No harsher activation conditions are required other than a KOH-carbon ratio of 4 at $700{ }^{\circ} \mathrm{C}$. The observed capacitance loss can be linked to the limited ionic conductivity $\left(8.4 \mathrm{mS} \cdot \mathrm{cm}^{-1}\right)$ and high viscosity (28.0 mPas) of EMI-TFSI [6]. For the conventional EDLC salt, TEABF 4 , conductivity reaches up to $60 \mathrm{mS} \cdot \mathrm{cm}^{-1}$ in acetonitrile [24] and $20 \mathrm{mS} \cdot \mathrm{cm}^{-1}$ in propylene carbonate [25].

Nyquist plots (Fig. 3b) show typical capacitive impedance response with a quasi-vertical line at the low frequency (except for AC2), and $\mathrm{a} \sim 45^{\circ}$ slope line in the medium frequency due to the porous electrode RC distribution [26,27]. Fig. 3b demonstrates a rather low series resistance, varying between 2.0 and $2.8 \Omega \cdot \mathrm{cm}^{2}$ for AC4-AC6 electrodes, whereas the in-pore ionic resistance fluctuates within $3.8-7.0 \Omega \cdot \mathrm{cm}^{2}$. 
The last confirms that the porosity of AC4 is well adapted to provide efficient ion transport with EMI-TFSI, and further pore enlargement is not needed for high power demand.

Both low series and in-pore resistance are comparable with the literature data for another ionic liquid with the same cation $\left(\mathrm{EMI}^{+} \mathrm{BF}_{4}^{-}\right)$[9]. In that case, carbons with a significant mesopore volume favoured more rapid in-pore ion transport, detrimentally to volumetric capacitance. By contrast, our results are obtained with the ACs of a $\mathrm{d}_{90}$ below $2 \mathrm{~nm}$, thereby suggesting that mesoporosity is not always required to ensure fast propagation of RTIL ions inside pores. Overall, impedance data also evidence efficient high-rate operation with RTILs and the studied microporous carbons.

\section{Conclusions}

In summary, microporous carbons from olive pits deliver a high capacitance of $180 \mathrm{~F} \cdot \mathrm{g}^{-1}$ and a low resistance of $4 \Omega \cdot \mathrm{cm}^{2}$ at room temperature in neat EMI-TFSI ionic liquid. This work reveals efficient capacitive response with RTILs and strictly microporous carbons, which also enables a high volumetric capacitance of $80 \mathrm{~F} \cdot \mathrm{cm}^{-3}$. Furthermore, carbons were prepared from biomass waste via a regular chemical activation procedure, which excludes complicated high-cost synthetic routes and synthetic precursors, and is therefore easily scalable.

Although the electrochemical behaviour showed good agreement with the ion-accessible area, it is still difficult to know the best carbon microstructure (PSD, relationship between ion-accessible SSA and volume ...) due to the lack of techniques to probe carbon geometric topology, and in-situ ion transport. Apart from the accessibility of pores to ions, other parameters, including surface chemistry and defects [28], need to be thoroughly investigated to provide detailed insight into the outstanding performance of microporous carbons in RTILs.

\section{Acknowledgments}

This work was funded by the Basque Government under the Etortek Energigune '12 (Project Reference IE12-335) and Elkartek 2015 (Project CICE2015, Reference KK-2015/0000100) Programs. W.-Y. T. was supported by the European Research Council (ERC, Advanced Grant, ERC-2011-AdG, Project 291543-IONACES).

\section{References}

[1] P. Simon, Y. Gogotsi, Materials for electrochemical capacitors, Nat. Mater. 7 (2008) 845-854.

[2] H. Ohno, Electrochemical Aspects of Ionic Liquids, 2nd edition, Wiley, 2011.

[3] A. Matic, B. Scrosati, Ionic liquids for energy applications, MRS Bull. 38 (2013) 533-537.

[4] D.R. Mac-Farlane, N. Tachikawa, M. Forsyth, J.M. Pringle, Patrick C. Howlett, G.D. Elliot, J.H. David, M. Watanabe, P. Simon, C.A. Angell, Energy applications of ionic liquids, Energy Environ. Sci. 7 (2014) 232-250.

[5] R. Mysyk, V. Ruiz, E. Raymundo-Piñero, R. Santamaria, F. Béguin, Capacitance evolution of electrochemical capacitors with tailored nanoporous electrodes in pure and dissolved ionic liquids, Fuel Cells 10 (2010) 834-839.

[6] N. Handa, T. Sugimoto, M. Yamagata, M. Kuta, M. Kono, M. Ishikawa, A neat ionic liquid electrolyte based on FSI anion for electric double layer capacitor, J. Power Sources 185 (2008) 1585-1588.

[7] A. Brandt, C. Ramirez-Castro, M. Anouti, A. Balducci, An investigation about the use of mixtures of sulfonium-based ionic liquids and propylene carbonate as electrolytes for supercapacitors, J. Mater. Chem. A 1 (2013) 12669-12678.

[8] R. Lin, P.L. Taberna, S. Fantini, V. Presser, C.R. Pérez, F. Malbosc, N.L. Rupesinghe, K.B.K. Teo, Y. Gogotsi, P. Simon, Capacitive energy storage from -50 to $100{ }^{\circ} \mathrm{C}$ using an ionic liquid electrolyte, J. Phys. Chem. Lett. 2 (2011) 2396-2401.

[9] L. Wei, M. Sevilla, A.B. Fuertes, R. Mokaya, G. Yushin, Polypyrrole-derived activated carbons for high-performance electrical double-layer capacitors with ionic liquid electrolyte, Adv. Funct. Mater. 22 (2012) 827-834.

[10] X. Wang, H. Zhou, E. Sheridan, J.C. Walmsley, D. Ren, D. Chen, Geometrically confined favourable ion packing for high gravimetric capacitance in carbon-ionic liquid supercapacitors, Energy Environ. Sci. 9 (2016) 232-239.

[11] M. Lazzari, F. Soavi, M. Mastragostino, Mesoporous carbon design for ionic liquidbased, double-layer supercapacitors, Fuel Cells 10 (2010) 840-847.

[12] E. Redondo, J. Carretero-Gonzalez, E. Goikolea, J. Segalini, R. Mysyk, Effect of pore texture on performance of activated carbon supercapacitor electrodes derived from olive pits, Electrochim. Acta 160 (2015) 178-184.

[13] M. Molina-Sabio, F. Rodriguez-Reinoso, Colloids Surf. A Physicochem. Eng. Asp. 241 (2004) 15-25.

[14] J. Jagiello, J. Oliver, 2D-NLDFT adsorption models for carbon slit-shaped pores with surface energetical heterogeneity and geometrical corrugation, Carbon 55 (2013) 70-80.

[15] P.L. Taberna, P. Simon, J.F. Fauvarque, Electrochemical characteristics and impedance spectroscopy studies of carbon-carbon supercapacitors, J. Electrochem. Soc. 150 (2003) A292-A300.

[16] C. Largeot, C. Portet, J. Chmiola, P.L. Taberna, Y. Gogotsi, P. Simon, Relation between the ion size and pore size for an electric double-layer capacitor, J. Am. Chem. Soc. 130 (2008) 2730-2731.

[17] N. Jäckel, P. Simon, Y. Gogotsi, V. Presser, Increase in capacitance by subnanometer pores in carbon, ACS Energy Lett. 1 (6) (2016) 1262-1265.

[18] A. Ahmadpour, D.D. Do, The preparation of active carbons from coal by chemical and physical activation, Carbon 34 (4) (1996) 471-479.

[19] C. Merlet, C. Pean, B. Rotenberg, P.A. Madden, B. Daffos, P.L. Taberna, P. Simon, M. Salanne, Highly confined ions store charge more efficiently in supercapacitors, Nat. Commun. 4 (2013) 1-6.

[20] L. Wei, G. Yushin, Nanostructured activated carbons from natural precursors for electrical double layer capacitors, Nano Energy 1 (2012) 552-565.

[21] S. Leyva-Garcia, D. Lozano-Castello, E. Morallon, T. Vogl, C. Schutter, S. Passerini, A. Balducci, D. Cazorla-Amoros, Electrochemical performance of a superporous activated carbon in ionic liquid-based electrolytes, J. Power Sources 336 (2016) 419-426.

[22] J. Chmiola, G. Yushin, Y. Gogotsi, P. Simon, P.L. Taberna, Anomalous increase in carbon capacitance at pore sizes less than 1 nanometer, Science 313 (5794) (2006) 1760-1763.

[23] H. Tamai, M. Kouzu, M. Morita, H. Yasuda, Highly mesoporous carbon electrodes for electric double-layer capacitors, Electrochem. Solid-State Lett. 6 (10) (2003) A214-A217.

[24] T. Devaraian, S. Higashiya, C. Dangler, M. Rane-Fondacaro, J. Snyder, P. Haldar, Novel ionic liquid electrolyte for electrochemical double layer capacitors, Electrochem. Commun. 11 (3) (2009) 680-683.

[25] M. Ue, Chemical capacitors and quaternary ammonium salts, Electrochemistry 75 (8) (2007) 565-572.

[26] M. Hahn, M. Baertschi, O. Barbieri, J.-C. Sauter, R. Kötz, R. Gallay, Interfacial capacitance and electronic conductance of activated carbon double-layer electrodes, Electrochem. Solid-State Lett. 7 (2004) A33-A36.

[27] C. Portet, P.L. Taberna, P. Simon, C. Laberty-Robert, Modification of Al current collector surface by sol-gel deposit for carbon-carbon supercapacitor applications, Electrochim. Acta 49 (2004) 905-912.

[28] G. Moussa, C.M. Ghimbeu, P.L. Taberna, P. Simon, C. Vix-Guterl, Relationship between the carbon nano-onions (CNOs) surface chemistry/defects and their capacitance in aqueous and organic electrolytes, Carbon 105 (2016) 628-637. 